\section{Sir John Pringle}

James Lind had a counterpart of equal greatness in the Army, and he too was a Scot. The Union of 1707 had made it possible for those of a poor country to find employment in the British dimension, something which will be lost at once if Scotland ever goes back to 17 th century days. Pringle was born in 1707 at Sitchel, began his medical career in St Andrews, moved to Edinburgh in 1727, but left for Leiden within a year. He joined the Army Medical Service of the day, was appointed Physician to the Army in Flanders in 1742 by Lord Stair, the C-in-C, and later Physician in Chief in 1745. At the Battle of Dettingen in 1743, under a 'Temporary Red Cross' and with the agreement of the Duc de Noailles, the French commander, British and French hospitals were set up side by side, each taking wounded from the other Army if the occasion arose. In this Pringle anticipated the Geneva Convention by 120 years.

Although Sir John left the Physician General's post in 1748, he did not publish his Observations on Diseases of the Army till 1752. Like Lind, Pringle had quickly recognised hospitals as, to use his own words, 'among the chief causes of sickness and death in the Army'. His special contribution was the first scientific account of epidemiology, of prevention of crossinfection and, it can be argued, of antisepsis. $\mathrm{He}$ had seen 'the small insects' under the microscope in Leiden, had noted the faeces as the likely carrier of infection in dysentery, and wrote: 'were putrefaction the only change made in the body by contagion, it would be easy to cure such fevers, at any period, by the use of acids, or other antiseptics'. His work deserves reading in detail and can be found in the Wellcome Medical History Institute in London. 